\title{
SSynthesis
}

International Scientific Conference of IT and Business-Related Research

\section{KOMPARATIVNA ANALIZA PRIVATNOG I DRŽAVNOG ELEKTRONSKOG NOVCA}

\section{COMPARATIVE ANALYSIS OF PRIVATE AND STATE \\ ELECTRONIC MONEY}

\author{
Nenad Tomić \\ Ekonomski fakultet Univerziteta u Kragujevcu, Đure Pucara Starog 3/D15, Kragujevac, Srbija
}

\begin{abstract}
Apstrakt:
Koncept elektronskog novca nalazio se $\mathrm{u}$ fokusu analize istraživača krajem XX veka. Razvoj informacionih i komunikacionih tehnologija (IKT), i začeci elektronskih oblika trgovine, stvorili su uslove i potrebu za razvoj odgovarajućeg sredstva plaćanja, koje bi bilo lako prenosivo u uslovima elektronskog poslovanja. Neuspeh ranih operativnih rešenja elektronskog novca je težište daljih istraživanja usmerio na druge mehanizme elektronskih plaćanja, dok je relativni značaj koncepta elektronskog novca smanjen. Sa pojavom Bitcoina, kao revolucionarnog oblika elektronskog novca, ovaj koncept ponovo dobija na značaju, što oživljava teoretske diskusije na temu primenjivosti i prihvatljivosti elektronskog novca. Kao protivteža ideji Bitcoina, koji je ne samo privatan, već i potpuno decentralizovan elektronski novac, javlja se predlog stvaranja državnog elektronskog novca, koji bi predstavljao dematerijalizovani oblik nacionalnih valuta. Cilj rada jeste da ukaže na prednosti i nedostatke dva pomenuta koncepta, i da utvrdi mogućnosti njihove operativne primene. $\mathrm{U}$ prvom delu rada analizirane su karakteristike koncepta elektronskog novca, dok je u drugom delu rada dat uporedni prikaz funkcionisanja privatnog i državnog elektronskog novca. U trećem delu je izvršena uporedna analiza ova dva modela, uz identifikovanje ključnih prednosti i nedostataka.
\end{abstract}

\section{Ključne reči:}

elektronski novac, Bitcoin, Giori standard, anonimnost, opšta prihvatljivost.

\section{UVOD}

Kvalitativne promene sistema plaćanja predstavljaju proces, uslovljen dostignutim nivoom civilizacijskog razvoja društva. Ograničenja nametnuta nesavršenošću robne razmene, prevaziđena su stvaranjem sistema novca zasnovanog na plemenitim metalima. Sledeći kvalitativni skok u evoluciji novca usledio je stvaranjem koncepta državnog papirnog novca, kada je po prvi put vrednost novca odvojena od vrednosti njegove fizičke osnove. Dok su prethodni oblici novca imali nemonetarnu upotrebu, na osnovu koje su posedovali monetarnu vrednost, papirni novac nema nemonetarnu primenu, pa monetarnu vrednost crpi iz državne garancije funkcionisanja ovog novčanog sistema.

Platni promet savremenih ekonomija funkcioniše na osnovama dualnog oblika novca:

- gotovog novca u vidu kovanica i papirnog novca,

- i depozitnog novca, koji predstavlja prvi dematerijalizovani oblik novca.

Iako regulativa u velikom broju zemalja dozvoljava stvaranje elektronskog novca, ni u jednoj ekonomiji još uvek ne postoji elektronski novac koji je zvanično sredstvo plaćanja.

\section{Abstract:}

The concept of electronic money was in the research focus at the end of the twentieth century. The development of information and communication technologies (ICT) and the early forms of electronic commerce have created conditions and the need for developing the appropriate means of payment, which would be easily transferable in terms of e-business. The failure of early operative solutions of electronic money has moved the focus of further research on other electronic payments mechanisms, while the relative importance of the concept of electronic money has been reduced. With the advent of Bitcoin, as a revolutionary form of electronic money, this concept is once again gaining importance, which revives theoretical discussion on the applicability and acceptability of electronic money. As a counterweight to the idea of Bitcoin, which is not only private but also completely decentralized electronic money, there is an idea to create state electronic money, which would be a dematerialised form of national currencies issued by central banks. The aim of this paper is to point out the advantages and disadvantages of these two concepts, and to determine the possibility of their operational use. The first part of the paper analyses the characteristics of the concept of electronic money, while the second part contains a comparative review of the functioning of private and state electronic money. The third part provides the comparative analysis of these two models, and identifies their key strengths and weaknesses.

\section{Key words:}

electronic money, Bitcoin, Giori standard, anonimity, general acceptability.

Ideja stvaranja elektronskog novca postoji već više od 3 decenije, i posledica je ubrzanog razvoja informaciono-komunikacionih tehnologija (IKT) početkom osamdesetih godina XX veka. Počeci elektronske trgovine, koja je korisnicima nudila mogućnosti udaljenog pristupa katalogu proizvoda, a u slučaju softverskih proizvoda i isporuke, stvorili su potrebu za razvojem efikasnog sredstva plaćanja, koje će omogućiti brzo i jeftino izvršavanje transakcija. Iako je u prethodnom periodu stvoreno više desetina operativnih modela elektronskog novca, nijedan nije postao prihvatljivo sredstvo plaćanja. Problem se javio u nemogućnosti ostvarenja masovne upotrebe, jer nijedan od stvorenih modela nije privukao dovoljan broj korisnika, kako na strani korisnika, tako ni na strani trgovaca zainteresovanih da svoju robu naplaćuju ovim novcem.

Sve kvalitativne promene sistema plaćanja izvedene su postupno, uz početne otpore i neprihvatanje korisnika. Nema sumnje da je razvoj elektronskog novca sledeći kvalitativni iskorak, čiji je proces integrisanja u sisteme plaćanja već otpočeo. S obzirom da žiralni novac već predstavlja dematerijalizovani oblik novca, elektronski novac nije potpuno revolucionalaran koncept na koji korisnici ne bi pristali. Otvoreno pitanje ostaje kakva treba da bude priroda budućih modela elektronskog 
novca, jer regulative vodećih zemalja ostavljaju mogućnosti da se kao emitenti elektronskog novca pojave i privatne i državne institucije.

Cilj rada je da se kroz uporednu analizu privatnog i državnog modela elektronskog novca ukaže na njihove potencijalne prednosti. U prvom delu rada biće analizirane opšte karakteristike elektronskog novca, dok će u drugom delu biti dat prikaz funkcionisanja privatnih sistema elektronskog novca sa primerom Bitcoina, a potom i mogućih državnih sistema, sa predlogom koji je dala kompanija Roberto Giori. U trećem delu biće izvršena uporedna analiza, i identifikovane prednosti i nedostaci datih sistema.

\section{POJAM I KARAKTERISTIKE ELEKTRONSKOG NOVCA}

Pojam elektronski novac prvi pominje Chaum (1983), analizirajući temu privatnosti kupaca koji plaćaju platnim karticama. Naglašavajući da plaćanja platnim karticama ostavljaju trag, na osnovu kojeg je moguće pratiti istoriju plaćanja korisnika, Chaum predlaže novo rešenje zasnovano na slepom potpisu proceduri potvrđivanja autentičnosti elektronskog dokumenta koji ovlašćenom telu ne ostavlja mogućnost da dalje prati kretanje potvrđenog dokumenta (Vuksanović, 2009, str. 148). Ovom inovacijom autor predlaže elektronski sistem plaćanja koji funkcioniše na osnovama gotovog novca, omogućavajući korisnicima privatnost prilikom plaćanja.

Ideje predstavljene u ovom radu analizirali su brojni autori. Stvaranje elektronskog ekvivalenta gotovini, koji bi zadržao sve poželjne karakteristike gotovog novca, uz omogućavanje brzog i nesmetanog toka posredstvom računarskih mreža, i kasnije interneta, činilo se logičnim rešenjem u trenutku kada je elektronska trgovina počela da ulazi u fazu ekspanzije. Sva operativna rešenja elektronskog novca su polazila od principa nemogućnosti praćenja (untraceability) transakcija, koji je predstavio Chaum, mada su često imala različite ključne karakteristike. Za dalju analizu sistema elektronskog novca neophodno je najpre utvrditi šta sve obuhvata ova kategorija.

Definisanje pojma elektronskog novca nije lako, usled činjenice da je moderno bankarstvo gotovo u potpunosti migriralo na elektronske osnove ili barem poluelektronske osnove poslovanja. Banka za međunarodna poravnjanja (BIS) u svom izveštaju iz 2000. godine definiše elektronski novac kao monetarna sredstva, odnosno vrednost, koja su pohranjena na uređaju koji je u vlasništvu korisnika, bez obzira da li je čuvanje te vrednosti zasnovano na hardverskoj osnovi (sredstva na kartici uplaćena kao prepaid) ili na softverskoj osnovi (program za rukovanje elektornskim novcem instaliran na hard disku računara). Po ovom tumačenju u elektronski novac ne spadaju proizvodi elektronskih kanala i tradicionalnih instrumenata plaćanja (npr. korišćenje kreditnih kartica u plaćanjima koja se obavljaju putem interneta). Sličnu kategorizaciju daje i Evropska komisija prilikom formulisanja Druge direktive elektronskog novca (2009/110/EC). Ovde dve kategorije elektronskog novca se navode kao „kartični“ i „serverski“ elektronski novac, što odgovara dvema kategorijama datim definicijom Banke za međunarodna poravnjanja. Pored toga, Evropska komisija uključila je i tzv. elektronske putničke čekove i elektronske vaučere, onda kada služe opštoj nameni, odnosno opštim plaćanjima. Iz kategorije elektronskog novca isključene su namenske prepaid kartice sa memorisanom monetarnom vrednošću, kada nemaju opštu namenu plaćanja, već služe za kupovinu jedne vrste proizvoda, ili kupovinu od jednog prodavca - drugim rečima, kartice za prevoz, kartice za telefonske govornice, kartice pojedinih izdavalaca kao što supermarketi i benzinske pumpe, koje služe za plaćanja samo u okvirima pravnih lica koja su izdala karticu.

Jednu od mogućih sistematizacija nudi i francuski autor Robert Guttmann (2003, str. 9) koji razdvaja kategorije elektronskog i tzv. sajber-novca. Pod elektronskim novcem autor podrazumeva sve kategorije plaćanja u kojima se koriste kanali zasnovani na informacionim tehnologijama (Internet, POS terminali) u kombinaciji sa platnim karticama (dakle, upravo ono što je BIS isključila iz svoje klasifikacije), dok pod terminom sajber-novac kao višom kategorijom podrazumeva „elektronske novčanike“ (kartice sa prepaid uplaćenom monetarnom vrednošću) i softverski novac kojim se raspolaže isključivo preko softvera instaliranog na računaru. Može se videti i da njegova kategorija sajber-novca odgovara kategoriji elektronskog novca BIS-a.

Elektronski novac kao novo sredstvo plaćanja trebalo bi da po svojim karakteristikama bude što bliži gotovom novcu, kako bi pogodovao za upotrebu u elektronskoj trgovini. Okamoto i Ohta (1991) navode šest karakteristika koje elektronska gotovina mora da poseduje kako bi krajnjim korisnicima bila prihvatljiva za upotrebu:

1. Sigurnost - elektronska gotovina mora garantovati visok stepen sigurnosti, u smislu da je nije moguće lako falsifikovati.

2. Anonimnost - ljudi i preduzeća će koristiti elektronsku gotovinu, ako nudi dimenziju anonimnosti koju nudi i gotovina u fizičkom svetu. Korisnici žele da imaju anonimnost kao opciju čak i onda kada im realno nije neophodna.

3. Prenosivost - elektronska gotovina ne bi trebalo da zavisi od bilo koje fizičke lokacije, tako da može da se prenosi slobodno putem računarskih mreža, kao i putem drugih uređaja koji služe za skladištenje, ili alternativnih sistema koji ne zavise od računara (kao što su mobilni telefoni).

4. Neograničeno trajanje - elektronska gotovina ne bi trebalo da istekne (da ima rok trajanja), uz pretpostavku da njen izdavalac neće bankrotirati ili prestati sa radom.

5. Visoka prihvatljivost - novac je samo ono sredstvo plaćanja koje je generalno prihvaćeno i kojim se može platiti drugim učesnicima u privrednom životu, nakon čega će i oni sami moći da ga potroše u istoj formi. Što je više i šire prihvaćen od strane korisnika, njegova upotrebna vrednost je veća. Ovaj uslov sigurno važi i za elektronsku gotovinu, koja treba da se proširi na peer-to-peer plaćanja.

6. Offline prihvatljivost - bilo bi korisno da elektronska gotovina može da ima neograničenu dostupnost tako da može biti potrošena bilo kada i bilo gde, bez neophodnosti da plaćanje bude vezano za upotrebu računara.

Pored ovih karakteristika, Jon Matonis današnji direktor Bitcoin fondacije (1995) dodaje još tri karakteristike:

1. Deljivost - elektronski novac bi trebalo da bude deljiv na manje jedinice. Mogućnost deljenja na manje novčane jedinice, poput gotovog novca, daje elektronskoj gotovini prednosti u Internet plaćanjima nad kreditnim karticama. Na ovaj način elektronski novac postaje poželjno sredstvo plaćanja za obavljanje mikroplaćanja.

2. Pogodnost za korišćenje - transakcija plaćanja elektronskom gotovinom mora da bude laka za izvođenje. Jednostavnost upotrebe je ključ za sticanje široke prihvatljivosti, posebno među novim Internet korisnicima kojima nedostaje iskustvo i samopouzdanje da se nose sa komplikovanim protokolom. 
3. Smanjenje uticaja države - ograničavanje mešanja države čini elektronsku gotovinu poželjnijim oblikom novca, jer se njena upotreba određuje tržišnim, a ne političkim okolnostima. Nema sumnje da je elektronska gotovina kao privatni oblik novca sposobna da efikasno izbegne državna ograničenja.

Od stepena ispunjenosti željenih karakteristika elektronskog novca zavisiće i uspešnost samog sistema. Guttmann (2003, str. 89) navodi da navedene karakteristike služe kao svojevrstan idealni model, ali da ipak nije jednostavno razviti sve ove karakteristike, delom zbog činjenice da su određene karakteristike međusobno u koliziji. Uzmimo kao primer sigurnost i anonimnost. Sigurnost prilikom korišćenja e-novca je od izuzetnog značaja. Ukoliko šema e-novca ne može da obezbedi sigurnost, korisnici neće biti zainteresovani za njegovu upotrebu. Međutim, kako se sigurnost korišćenja može obezbediti uvidom u sve transakcije korisnika, izvodi se zaključak da je sigurnost u koliziji sa anonimnošću

Atributivne karakteristike elektronskog novca su široka prihvatljivost i unapred izvršena uplata kupovne snage. Prva karakteristika se odnosi na već pomenuto razdvajanje jednonamenskih i višenamenskih elektornskih instrumenata plaćanja, pri čemu u elektronski novac spadaju samo višenamenski serverski ili kartični elektronski novac. Druga karakteristika se odnosi na obavezu korisnika da izvšri „kupovinu“ elektronskog novca unapred, tj. da uplati određeni iznos konvertibilnog novca u zamenu za elektronski. Ova karakteristika mora biti zadovojena, bez obzira da li se radi o kartičnom ili serverskom elektronskom novcu (Vuksanović 2001, str. 88).

\section{PRINCIPI FUNKCIONISANJA MODELA ELEKTRONSKOG NOVCA}

Da bi se podstakao razvoj sistema elektronskog novca, Evropska unija je donela dve Direktive o elektronskom novcu, prvu 2000. godine, i drugu 2009. godine. Cilj Direktiva je detaljno uređenje poslova izdavanja elektronskog novca, počev od neophodnih uslova koje kompanije emitenti treba da zadovolje, do samog izdavanja i obaveza u održavanju sistema. Direktivom 2009/110/EC dopunjene su i izmenjene odredbe prethodno važeće Direktive 2000/46/EC, čime je ova prestala da važi. Novom Direktivom ustanovljeni su sledeći pojmovi:

- „institucija elektronskog novca” (EMI) je pravno lice koje je dobilo odobrenje za izdavanje elektronskog novca;

- „elektronski novac” je elektronski i magnetno, pohranjena monetarna vrednost, koja predstavlja potraživanje prema njegovom izdavaocu, i izdata je nakon prijema novčanih sredstava;

- „izdavaoci elektronskog novca” su subjekti koji ostvaruju korist od izdavanja elektronskog novca, kao i pravna lica koja se bave istim poslom;

- „prosečan iznos elektronskog novca u opticaju” je prosečan ukupni iznos finansijskih dugovanja vezanih za izdavanje elektroskog novca na kraju svakoga kalendarskog perioda tokom prethodnih šest meseci.

Govoreći o EMI, Direktiva 2009/110/EC predviđa da se u ulozi izdavaoca elektronskog novca mogu naći i državne i privatne institucije, pri čemu se dalje određuju uslovi koji moraju biti zadovoljeni. Pored postojanja pravnog okvira, državne institucije se do sada nisu bavile izdavanjem elektronskog novca, kako u EU, tako ni u SAD-u.

\subsection{PRINCIPI FUNKCIONISANJA PRIVATNIH MODELA}

Pre svega, treba naglasiti da su emitenti svih reprezentativnih modela elektronskog novca do sada bili privatne institucije. Po načinu funkcionisanja, privatne modele možemo podeliti na centralizovane i decentralizovane modele.

Centralizovani modeli elektronskog novca karakteristični su za ranu fazu, devedesete godine XX veka i sam početak XXI veka, a odlikuje ih jedna institucija izdavalac, koja je odgovorna za kreiranje i održavanje sistema, i koja ostvaruje operativne prihode od funkcionisanja. Gotovo po pravilu, emitenti su bili nebankarske institucije, u najvećem broju slučajeva softverske kompanije. Ideja ovih kompanija bila je da se proces kreiranja infrastrukture sistema, i kasnije održavanje izvede vlastitim resursima, čime bi se omogućile uštede u programerskim aktivnostima.

Kao primer se može navesti kompanija DigiCash sa svojim modelom elektronskog novca eCash, i kompanije Flooz i Beenz sa istoimenim modelima. Sve tri pomenute kompanije samostalno su razvijale softverske osnove sistema, naročitu pažnju posvećujući karakteristikama anonimnosti i sigurnosti, kao ultimativnim karakteristikama elektronskog novca. I pored toga što su sva tri modela bila adekvatno softverski razvijena i održavana, kompanije nisu uspele da ih održe duže od dve godine, jer su troškovi poslovanja bili viši od operativnih prihoda. Nijedna od tri kompanije nije imala adekvatnu marketinšku strategiju privlačenja klijenata, ni na strani trgovaca, ni na strani krajnjih korisnika.

Kod sva tri modela problem je bio način motivisanja klijenata da prihvate korišćenje elektronskog novca. Onlajn trgovce trebalo je navesti na prihvatanje plaćanja u novcu koji koristi neznatan broj krajnjih korisnika, dok je krajnjim korisnicima trebalo prodati novac kojim mogu plaćati u malom procentu online kupovina. Imajući u vidu da govorimo o kraju XX veka, obim elektronske trgovine bio je na više puta nižem nivou od današnjeg, uz višestruko manji broj kupaca i prodavaca. U takvim okolnostima mali broj korisnika na strani trgovaca i krajnjih korisnika značio je nižu mogućnost zarade za kompaniju emitenta.

Guttmann (2003, str. 117) zaradu od emisije elektronskog novca označava pojmom digitalna senjoraža, analogno senjoraži koja predstavlja prihod emitenta konvertibilnog novca. Mogućnosti ostvarenja digitalne senjoraže su direktne i indirektne. Direktna digitalna senjoraža podrazumeva ostvarenje finansijske koristi emitenta kroz naplatu pretplate za članstvo u sistemu, kroz primenu različitih kurseva za prodaju i otkup elektronskog novca, ili kroz naplatu provizije za procesiranje transakcija. Nivo ostvarenih prihoda u ovom slučaju je direktno proporcionalan nivou aktivnosti klijenata. Indirektna digitalna senjoraža ne podrazumeva finansijsku korist povezanu sa korišćenjem samog elektronskog novca, već korist koja se ostvaruje usled stvaranja brenda emitenta, koji je uz elektronski novac u mogućnosti da ponudi krajnjim korisnicima paket srodnih usluga. Indirektan oblik digitalne senjoraže više odgovara emitentima koji su bankarske ili uopšteno finansijske institucije, i koji mogu putem emisije elektronskog novca da ostvare ekonomiju opsega.

Negativni aspekt digitalne senjoraže je nemogućnost primene u novim i nedovoljno masovnim sistemima. Emitent teško može da naplati visoku pretplatu onlajn trgovcu za pristup sistemu, ako postoji veoma mali broj krajnjih korisnika zainteresovanih za plaćanje elektronskim novcem. Ukoliko je razlika između dva kursa visoka, ni korisnici ni trgovci neće biti zain- 
teresovani da koriste elektronski novac, jer će cene proizvoda posmatrati iz dijametralno suprotnih uglova. Konačno, visoki troškovi transakcija smanjiće atraktivnost korišćenja elektronskog novca za online plaćanja u odnosu na kreditne kartice, naročito u domenu mikrotransakcija.

Kompanija DigiCash sklopila je dogovor sa više banaka koje je trebalo da posluju kao agenti za eCash, nudeći ga svojim klijentima (fizičkim licima i kompanijama). Cilj je bio ostvariti zaradu na osnovu članstva u sistemu. Beenz se odlučio za različite kurseve kupovine i prodaje svoje elektronske valute, pri čemu je razlika bila dvostruka (100 Beenz-a se moglo dobiti za jedan američki dolar, dok je pri prodaji bilo potrebno $200 \mathrm{Be}$ enz-a za kupovinu jednog američkog dolara). Kako nijedan od tri modela nije dostigao zrelost u kojoj je moguće ostvariti viši obim prihoda, kompanije koje su ih dizajnirale su bankrotirale nakon oko dve godine rada (Junnarkar, 2001; Wearden, 2001).

Decentralizovane modele elektronskog novca odlikuje ekonomska nezavisnost od same institucije izdavaoca, jer veći broj nezavisnih korisnika učestvuje u upravljanju/održavanju mreže. Prvi model ovog koncepta elektronskog novca je Bitcoin, kod koga praktično ne postoji institucija izdavalac. Izdavanje novih novčića reguliše moćan algoritam (Nakamoto, 2008), programiran da na osnovu odabrane hash funkcije u intervalima od približno 10 minuta dodeljuje registrovanim korisnicima određeni broj novčića. Novčići se dobijaju kao nagrada za učestvovanje u održavanju sistema. Dakle, decentralizacija se ogleda u odsustvu jedinstvenog entiteta emitenta elektronskog novca, i jedinstvenog entiteta koji održava sistem. Umesto toga, unapred stvoreni algoritam reguliše sistem uz pomoć registrovanih korisnika koji pomažu njegovo održavanje. Korisnici uz pomoć algoritma sprečavaju dvostruko trošenje novca, uz istovremeno očuvanje principa anonimnosti transakcija.

Ovakvim dizajnom posao održavanja sistema sa svim pratećim troškovima prenesen je na krajnje korisnike. Time je eleminisana opasnost da Bitcoin prestane sa funkcionisanjem zbog neekonomičnog poslovanja entiteta koji upravlja sistemom. Kreatori sistema su svakako podneli velike troškove tokom dizajniranja algoritma, ali su ovi troškovi brzo mogli da budu nadoknađeni time što su prve kreirane novčiće preuzeli upravo oni sami. U takvoj situaciji, kreatori su mogli preuzeti dovoljno veliku bazu novčića, da svoj trud višestruko isplate, dok se celokupan trošak održavanja sistema prenosi na krajnje korisnike. Troškovima održavanja sistema mogu se smatrati troškovi amortizacije opreme, i utrošene električne energije, koja se potroši u radu registrovanih članova koji održavaju Bitcoin sistem. Prenošenjem troškova održavanja sistema na veliki broj pojedinačnih korisnika, ukupni troškovi se prikrivaju i čine nižim nego što zaista jesu. Tek ako bi se izračunali troškovi svih pojedinačnih registrovanih članova, i uporedili sa vrednošću generisanih elektronskih novčića, moglo bi se utvrditi da li je postojanje sistema ekonomski opravdano.

Da je model Bitcoina ekonomski isplativ kreatorima sistema govori stvaranje velikog broja modela koji funkcionišu na njegovim osnovama. Litecoin, Alphacoin, Dogecoin, samo su neki od preko deset novih modela nastalih u poslednje dve godine, koji funkcionišu kao Bitcoin kopije.

Najveći nedostatak svih centralizovanih modela elektronskog novca, nedovoljna prihvatljivost kod korisnika i trgovaca, nije rešena ni decentralizovanim modelima. Ni Bitcoin, ni kasniji modeli nisu postali sredstvo plaćanja u elektronskoj trgovini, osim u nekim specifičnim nišama. Tako se Bitcoin veoma često dovodi u vezu sa finansiranjem nelegalnih aktivnosti i trgovinom zabranjenim proizvodima i uslugama. Generalni zaključak je da stepen centralizovanosti jednog modela elektronskog novca ne utiče presudno na poslovnu uspešnost tog modela.

\subsection{PRINCIPI FUNKCIONISANJA DRŽAVNIH MODELA}

Iako regulativa dozvoljava mogućnost emitovanja elektronskog novca od strane centralnih banaka, državnih organa vlasti ili organa vlasti lokalnih samouprava, u dosadašnjoj praksi nije zabeležen slučaj državnog elektronskog novca. Slabosti privatnih modela elektronskog novca stvorile su dovoljno prostora za razvoj državnog modela, koji bi samom činjenicom da iza njega stoji država mogao da reši neke od ključnih problema privatnih modela.

Bez obzira na opsežne radnje preuzete prilikom dizajniranja sistema, u cilju očuvanja bezbednosti korisnika i sprečavanja dvostrukog trošenja novca, korisnici nemaju dovoljno poverenja u elektronski novac. Uzroci nedostatka poverenja su pri tome pre nestabilnost vrednosti i mala mogućnost upotrebe elektronskog novca, nego disfunkcionalnosti sistema. Rešenje koje nudi Roberto Giori Company (RGC) moglo bi ispraviti neke od ovih problema.

U dualnom sistemu novca, paralelno funkcionišu gotov novac i žiralni novac. Samim tim, koncept dematerijalizacije novca nije potpuno nova ideja, jer je moguće vršiti plaćanja i primati sredstva žiralnim novcem bez ikakvog fizičkog kontakta sa ekvivalentnim iznosom gotovine. Državni elektronski novac koji RGC predlaže razlikovao bi se od žiralnog novca po tome što za njegovu upotrebu nisu neophodni bankovni računi, niti učešće finansijskih posrednika. Monetarna vrednost čuvala bi se na memoriji mobilnog telefona ili prenosnog računara, i mogla bi da slobodno cirkuliše među korisnicima. Ograničenje u cirkulaciji ovog novca bi pri tome bila raspoloživost uređaja kojima se može prenositi, a ne posedovanje adekvatnog računa u banci. Na ovaj način elektronski novac bi posedovao karakteristike kako gotovog novca, tako i žiralnog.

RGC je vodeća svetska kompanija u oblasti proizvodnje i održavanja opreme za štampanje novčanica, ranije i državnih hartija od vrednosti. U kontekstu informatičkog društva, i postepenog prelaska poslovnih procesa na elektronske osnove, RGC državama nudi dve platforme, Giori digitalni novac (Giori digital money) i Giori standard za tehnologiju novca (Giori standard money technology). Prva platforma odnosi se na algoritam za izradu i distribuciju elektronskih novčanica, njihovo slepo potpisivanje i mogućnost provere autentičnosti. Druga platforma se odnosi na praćenje izvršenih transakcija i sprečavanje dvostrukog trošenja emitovanog novca. Kroz ove dve platforme, centralne banke bi dobile potpun set alata za izdavanje državnog elektronskog novca, koji bi bio zakonsko sredstvo plaćanja baš kao i papirni i žiralni državni novac.

$\mathrm{Na}$ ovaj način centralne banke bi zadržale kontrolu nad ponudom novca, jer emisija elektronskog novca ne bi morala da poveća ukupnu ponudu novca, ako se npr. sprovodi restriktivna monetarna politika putem povećanja stope obaveznih rezervi. Za razliku od privatnih modela elektronskog novca, ne bi postojao problem niske stope prihvatanja u transakcijama, jer bi postojala obaveza prihvatanja zakonskog sredstva plaćanja, baš kao što postoji za gotov novac i žiralni novac. Ovakav model elektronskog novca omogućio bi anonimnost plaćanja na isti način na koji to čini gotov novac - novčanice bi bile slepo potpisane i imale serijske brojeve radi obezbeđenja od falsifikovanja, ali ne bi bilo moguće pratiti transakcije. Konačno, zbog odsustva potrebe da se transakcije izvode uz asistenciju posrednika, krug korisnika elektronskog novca mogao bi biti mnogo širi nego krug korisnika žiralnog novca. 


\section{UPOREDNA ANALIZA PREDNOSTI I NEDOSTATAKA DRŽAVNOG I PRIVATNOG ELEKTRONSKOG NOVCA}

Pored neuspeha svih ranih modela elektronskog novca da se održe, odnosno nemogućnosti Bitcoin-a da se nametne kao sredstvo plaćanja, u bližoj budućnosti se može očekivati stvaranje elektronskog novca koji bi postao globalno sredstvo plaćanja u elektronskoj trgovini. Korisnici koji ne poseduju ni jedan bankovni račun, kao što su recimo tinejdžeri, nemaju uslove za plaćanja karticom ili PayPal-om, pa bi za njih ovakav sistem bio idealan. Da bi elektronski novac privatnog izdavača bio prihvatljiv na globalnom nivou, morala bi ga podržati međunarodna organizacija, što je manje verovatno, ili konzorcijum velikih kompanija, što je više realna opcija. U konzorcijumu bi se morala naći jedna ili više velikih finansijskih kompanija, ali i jedna ili više kompanija iz IT domena, pri čemu bi to mogla biti softverska kompanija, Internet gigant, veliki online trgovac ili čak proizvođač hardvera. Između ostalog, mobilni operateri i veliki trgovinski lanci su takođe adekvatni partneri. Veliki konzorcijum bi garantovao adekvatan nivo prihvatljivosti ovog novca, pa bi bilo ostavljeno više prostora za dizajn sistema i zadovoljenje ostalih poželjnih karakteristika. Koliko je ovakav razvoj događaja daleko zavisi od razvoja događaja u narednih nekoliko godina, a u dobroj meri i od sudbine Bitcoin- $a$.

Sve institucije koje bi činile ovaj konzorcijum imale bi ulogu da privuku što veći broj svojih postojećih korisnika. Ovaj posao ne bi bio posebno namenjen bankama jer su i druge kompanije već imale uspeha u pružanju nekih finansijskih usluga, poput Google-a sa digitlanih novčanikom (Google Wallet), velikih supermarketa sa platnim karticama koje izdaju ili mobilnih operatera sa uslugama mobilnog bankarstva koje pružaju. Svaki od članova konzorcijuma imao bi obavezu da prihvata plaćanja u elektronskom novcu, kako bi kod korisnika stvorio svest o širokoj prihvatliivosti. Problem koji se u konzorcionom pristupu može javiti je nemogućnost stvaranja dovoljno širokog konzorcijuma sastavljenog od jakih tržišnih igrača sa pojedinačnih tržišta. Veoma težak posao bi bio napraviti od kompanija dominantnih u svojim segmentima poslovanja timske igrače koji će u konzoricjumu biti ravnopravni (Ozcan \& Santos, 2014).

Koncept državnog elektronskog novca omogućava da država (centralna banka) zadrži digitalnu senjoražu - prihod od izdavanja ovakvog oblika novca. Troškovi izdavanja ovog oblika novca daleko su niži od troškova dva aktuelna oblika - gotovog i žiralnog novca. Dok se za ova dva oblika vezuju dominantno varijabilni troškovi, koji zavise od obima štampanja papirnog novca, odnosno broja transakcija žiralnim novcem, elektronski novac produkovao bi dominantno fiksne troškove, koji bi bili posledica nabavke opreme i tehnologije emisije i praćenja ovog novca, dok bi troškovi samog stvaranja novih digitalnih novčanica bili bliski nuli. Eventualnim pravnim rešenjima, moglo bi se obezbediti praćenje transakcija, čime bi se uz žrtvovanje anonimnosti mogla pratiti plaćanja u cilju sprečavanja finansiranja terorizma, pranja novca i izbagavanja poreza.

Što se tiče krajnjih korisnika, najveću korist mogu ostvariti grupe stanovništva kojima su platne kartice i onlajn sistemi plaćanja nedostupni - grupe sa niskim dohotkom, mladi i penzioneri (uz pretpostavku da ne pokažu veliki otpor u prihvatanju inovacije). Državni elektronski novac bi se u maloprodaji ponašao kao zamena za gotovinu, dok bi upotrebom za plaćanja na daljinu imao ulogu supstituta žiralnog novca, i svih sistema onlajn plaćanja koji se zasnivaju na žiralnom novcu.

Za eventualno uvođenje državnog elektronskog novca u upotrebu neophodno bi bilo izmeniti postojeću regulativu. Iako
Direktiva 2009/110/EC omogućava da državni i lokalni organi vlasti budu emitenti elektronskog novca, za punu primenu ovog koncepta u EU morali bi se izmeniti Ugovor o funkcionisanju Evropske unije (Treaty on the functioning of The European Union - TFEU), i Direktiva o platnim uslugama (Directive 2007/64/ EC). Član 128. TFEU navodi da su jedino zakonsko sredstvo plaćanja u Evropskoj uniji novčanice koje izdaje Evropska centralna banka i nacionalne centralne banke. Ovaj član bi trebalo izmeniti i dopuniti elektronskim novcem. Izmene bi morale biti učinjene i u nacionalnim zakonodavstvima. Međutim, ovo je veoma teško izvesti, jer zahteva koordinaciju ne samo nacionalnih zakonodavnih vlasti, već i vlasti na nivou EU, koja ne deluje kao prosti zbir nacionalnih vlasti. Uvođenje državnog elektronskog novca bi mnogo brže i efektnije bilo u SAD-u ili nekoj manjoj ekonomiji, imajući u vidu složenost evropskog zakonodavstva.

\section{ZAKLJUČAK}

Prošle su gotovo dve decenije od prvih modela elektronskog novca, bez suštinskog napretka ka stvaranju opšte prihvatljivog elektronskog novca. Dok su dizajneri sistema brinuli o anonimnosti i bezbednosti sistema, svi modeli su jedan za drugim padali na testu prihvatanja korisnika. Anonimnost nije ultimativna karakteristika elektronskog novca. Stvaranje elektronske gotovine koja bi verno očuvala što više osobina gotovog novca u fizičkom obliku sasvim sigurno je poželjna za razvoj modela elektronskog novca, ali nije presudna osobina koja će garantovati uspeh. Sva nastojanja kreatora elektronskog novca da anonimnošću privuku korisnike pokazala su se pogrešnim, za šta je dokaz primer PayPal-a.

Na neki način, elektronski novac je postao žrtva prevelikog uvećanja brzine evolucije IT sistema. Tehnička izvodljivost elektronskog novca došla je pre realne društvene potrebe za implementacijom ovakvih sistema, jer nije postojala kritična masa korisnika elektronske trgovine koji žele promenu u načinu plaćanja. Tome treba dodati da se među korisnicima uvek nađu rani usvajači, skloni inovacijama, ali i korisnici otporni na promene. U vremenu kada su postojali korisnici koji su odbijali upotrebu platnih kartica u prodavnicama, elektronski novac bi sasvim sigurno imao poteškoće da privuče veliki broj potrošača, čak i da se veći broj onlajn trgovaca opredeli za neko od aktuelnih rešenja.

Nema sumnje da je elektronski novac sledeći korak u evoluciji novca. U kom obliku će se elektronski novac nametnuti zavisi od mnogo faktora. Bezbednost sistema, ekonomska isplativost i jednostavnost korišćenja, samo su neke od poželjnih karakteristika, ali nijedna ne može zameniti opštu prihvatljivost, kao presudnu karakteristiku koja utiče na uspeh jednog modela. Država bi kao emitent imala jasnu komparativnu prednost u obezbeđivanju prihvatanja elektronskog novca koji emituje kroz zakonsku prinudu. Sa druge strane, privatni konzorcijum mogao bi stvoriti elektronski novac koji nije zakonsko sredstvo plaćanja, ali je prihvatljiv kod dovoljno velikog broja trgovaca, tako da krajnji korisnici imaju motiv da ga koriste. Razvoj oba koncepta takođe ima i neka realna ograničenja koja su analizirana u radu. Može se očekivati da će preferencije i potrebe korisnika imati presudan uticaj na evoluciju koncepta elektronskog novca.

\section{LITERATURA}

Bank for International Settlements. (2000). Survey of electronic money development. Preuzeto 30. marta 2015. sa http:// www.bis.org/cpmi/publ/d38.htm 
Chaum, D. (1983). Blind signatures for untraceable payments. Advances in Cryptology: Proceedings of Crypto '82. DOI: 10.1007/978-1-4757-0602-4_18

European Commission. (2007). Consolidated version of the Treaty on the Functioning of the European Union. Official Journal of European Union, C 326. Preuzeto 30. Marta 2015. sa http://eur-lex.europa.eu/legal-content/EN/ TXT/?uri=CELEX:12012E/TXT

European Commission. (2007). Directive 2007/64/EC on payment services in the internal market. Official Journal of European Union, L 319/1. Preuzeto 30. marta 2015. sa http://eur-lex. europa.eu/LexUriServ/LexUriServ.do?uri=OJ:L:2007:319:0 001:0036:en:PDF

European Commission. (2009). Directive 2009/110/EC on the taking up, pursuit and prudential supervision of business of the electronic money institutions. Official Journal of European Union, L 267/7. Preuzeto 30. Marta 2015. sa http://eur-lex. europa.eu/LexUriServ/LexUriServ.do?uri=OJ:L:2009:267:0 007:0017:EN:PDF

Giori, R. (2014). Towards legal digital money: Issued by the Central Bank. Switzerland: The Roberto Giori Company LTD.

Guttmann, R. (2003) Cybercash: The coming era of electronic money. New York: Palgrave Macmillan.
Junnarkar, S. (2001) Benz.com seeks buyer. Preuzeto 30. Marta 2015. sa http://news.cnet.com/Beenz.com-seeks-buyer/2100-1017_3-254984.html

Matonis, J. (1995) Digital cash and monetary freedom. Economic Notes No. 63. Preuzeto 30. marta 2015. sa http://libertarian. co.uk/lapubs/econn/econn063.pdf

Nakamoto, S. (2008) Bitcoin: A peer-to-peer electronic cash system. Preuzeto 30. marta 2015. sa http://Bitcoin.org/Bitcoin.pdf

Okamoto, T., \& Ohta, K. (1991). Universal electronic cash. Advances in Cryptology- CRYPTO'91: Proceedings. DOI: 10.1007/3-540-46766-1_27

Ozcan, P., \& Santos, F.M. (2014). The market that never was: Turg wars and failed alliances in mobile payments. Strategic Management Journal. DOI: 10.1002/smj.2292

Vuksanović, E. (2001) Elektronski novac: značajno unapređenje ili radikalna promena. Ekonomski horizonti, 3(1-2), str. 83-95.

Vuksanović, E. (2009) Elektronski sistemi plaćanja. Kragujevac: Ekonomski fakultet Univerziteta u Kragujevcu.

Wearden, G. (2001) Flooz.com collapse linked to massive credit card fraud. Preuzeto 30. marta 2015. sa http://www.zdnet. com/article/flooz-com-collapse-linked-to-massive-creditcard-fraud/ 